\title{
A combination of HPLC and automated data analysis for monitoring the efficiency of high-pressure homogenization
}

\author{
Britta Eggenreich', Vignesh Rajamanickam¹,2, David Johannes Wurm¹, Jens Fricke ${ }^{1,2}$, Christoph Herwig ${ }^{1,2}$ \\ and Oliver Spadiut ${ }^{*^{*}}$ (D)
}

\begin{abstract}
Background: Cell disruption is a key unit operation to make valuable, intracellular target products accessible for further downstream unit operations. Independent of the applied cell disruption method, each cell disruption process must be evaluated with respect to disruption efficiency and potential product loss. Current state-of-the-art methods, like measuring the total amount of released protein and plating-out assays, are usually time-delayed and involve manual intervention making them error-prone. An automated method to monitor cell disruption efficiency at-line is not available to date.
\end{abstract}

Results: In the current study we implemented a methodology, which we had originally developed to monitor E. coli cell integrity during bioreactor cultivations, to automatically monitor and evaluate cell disruption of a recombinant E. coli strain by high-pressure homogenization. We compared our tool with a library of state-of-the-art methods, analyzed the effect of freezing the biomass before high-pressure homogenization and finally investigated this unit operation in more detail by a multivariate approach.

Conclusion: A combination of HPLC and automated data analysis describes a valuable, novel tool to monitor and evaluate cell disruption processes. Our methodology, which can be used both in upstream (USP) and downstream processing (DSP), describes a valuable tool to evaluate cell disruption processes as it can be implemented at-line, gives results within minutes after sampling and does not need manual intervention.

Keywords: Cell disruption, High-pressure homogenization, E.coli, HPLC, Data analysis

\section{Background}

Biopharmaceuticals represent the most valuable product class on the pharmaceutical market today [1]. The first recombinant biopharmaceutical, a human insulin analogue, was produced in E. coli and introduced to the market already in 1982 [1, 2]. Since then, E. coli has become one of the most important host organisms for the recombinant production of biopharmaceuticals. Currently, more than $25 \%$ of approved biopharmaceuticals are expressed in this organism [3]. This can easily be

\footnotetext{
*Correspondence: oliver.spadiut@tuwien.ac.at

${ }^{1}$ Research Division Biochemical Engineering, Institute of Chemical, Environmental and Biological Engineering, TU Wien, Gumpendorfer Strasse 1a, 1060 Vienna, Austria

Full list of author information is available at the end of the article
}

explained as E. coli allows fast growth in defined media and gives high product titers in scalable processes, resulting in economic production processes $[1,2,4]$. However, E. coli cannot perform post-translational modifications, limiting the product range that can be produced in a soluble and active form in this host organism [5]. Furthermore, E. coli cannot secrete recombinant proteins. Consequently, recombinant $E$. coli cells need to be disrupted to access the intracellular product, which is then usually purified by several steps of filtration and chromatography [5-7]. A typical recombinant E. coli protein production process is schematically shown in Fig. 1.

As shown in Fig. 1, the downstream process usually starts with the unit operation "Cell disruption". There is a variety of different methods available to disrupt $E$. coli 


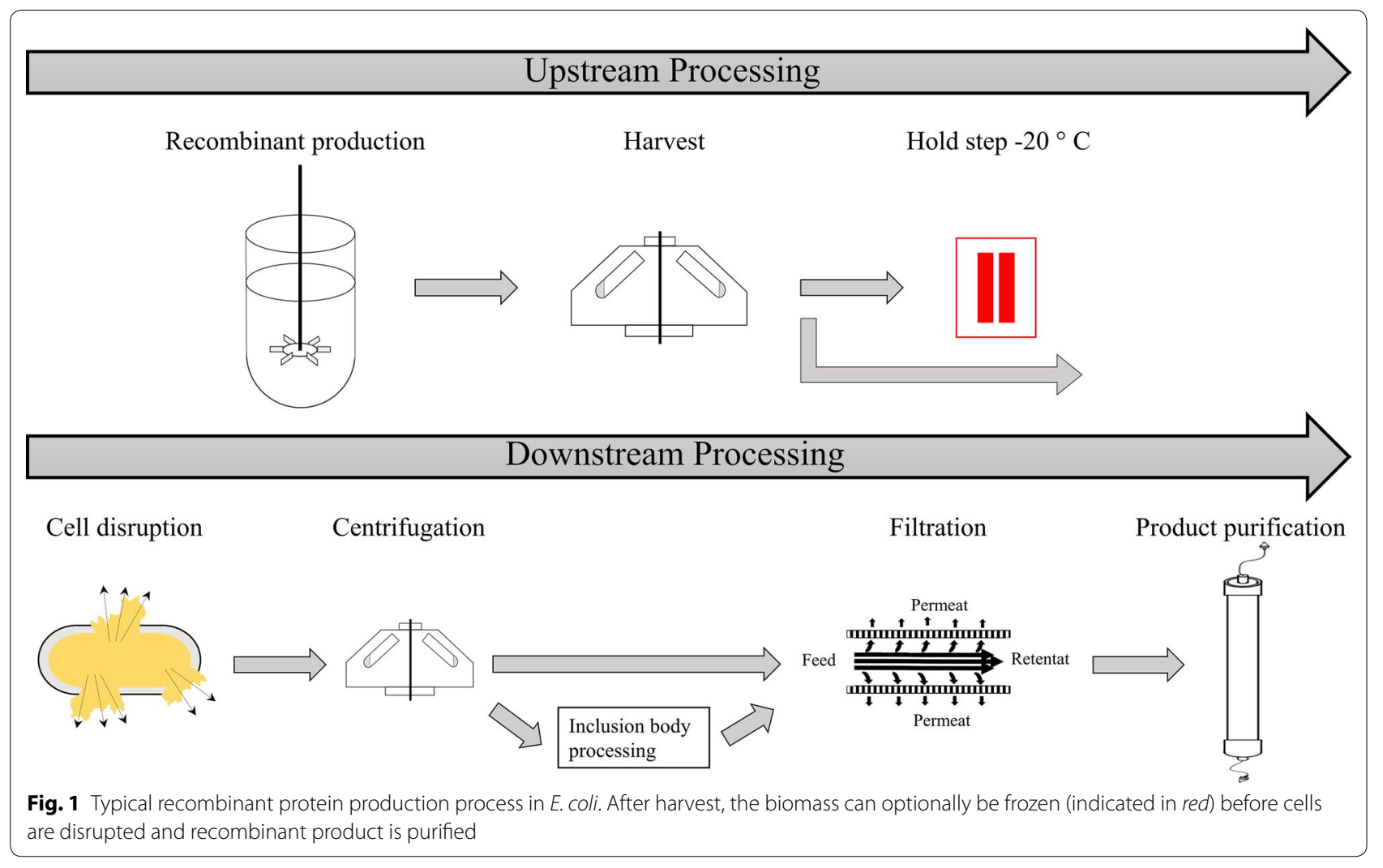

cells and make the intracellular product accessible. In Table 1, the most common principles and methods for cell disruption as well as the respective advantages and disadvantages are summarized.

Independent of the applied cell disruption principle and the respective method, each cell disruption process must be evaluated with respect to disruption efficiency and potential product loss. On the one hand, cell disruption must be efficient to obtain the maximum of intracellular product. On the other hand, however, excessive treatment of the cells might negatively affect the highly valuable product. The most common methods to evaluate cell disruption efficiency and their respective advantages and disadvantages are summarized in Table 2.

As shown in Table 2, the current state-of-the-art methods to evaluate cell disruption efficiency are usually offline and time-consuming and often need manual intervention making them highly error-prone. Thus, there is a demand for a methodology that allows automated evaluation of cell disruption efficiency without great time delay.

Table 1 Most common cell disruption principles, respective methods as well as advantages and disadvantages

\begin{tabular}{|c|c|c|c|c|}
\hline $\begin{array}{l}\text { Principle of cell } \\
\text { disruption }\end{array}$ & Method & Advantages & Disadvantages & References \\
\hline Chemical & Detergents, solvents, acid, base & $\begin{array}{l}\text { Standard lab equipment sufficient, } \\
\text { selective release }\end{array}$ & $\begin{array}{l}\text { Expensive, not scalable, not } \\
\text { controllable }\end{array}$ & {$[8-11]$} \\
\hline Biological & Lysozyme & Standard lab equipment sufficient & $\begin{array}{l}\text { Expensive, not scalable, additional } \\
\text { impurity }\end{array}$ & {$[12,13]$} \\
\hline \multirow[t]{4}{*}{ Physical } & Freeze-thawing & Standard lab equipment sufficient & Not scalable, inefficient & {$[14]$} \\
\hline & Acoustic cavitation & Fast, efficient, easy handling & Not scalable, time consuming & {$[12,14,15]$} \\
\hline & Hydrodynamic cavitation & Selective release & Inefficient, not scalable & {$[10,16,17]$} \\
\hline & Osmotic shock & Selective release & Time consuming, not scalable & {$[10,11,18]$} \\
\hline \multirow[t]{2}{*}{ Mechanical } & Grinding (e.g. bead mill) & Efficient & $\begin{array}{l}\text { Time consuming, not scalable, } \\
\text { generation of heat }\end{array}$ & {$[10,11,14,15]$} \\
\hline & High-pressure homogenization & Efficient, scalable & Generation of heat & {$[13,15,18-21]$} \\
\hline
\end{tabular}


Table 2 Common methods to evaluate cell disruption efficiency

\begin{tabular}{|c|c|c|c|c|}
\hline Answer & Method & Advantage & Disadvantage & References \\
\hline Total protein release & $\begin{array}{l}\text { Protein concentration (e.g. Brad- } \\
\text { ford, Lowry) }\end{array}$ & $\begin{array}{l}\text { Relatively fast, standard lab equip- } \\
\text { ment sufficient }\end{array}$ & $\begin{array}{l}\text { Matrix interference, manual } \\
\text { intervention }\end{array}$ & {$[8,15,18,21]$} \\
\hline \multirow[t]{2}{*}{ Cell viability } & Microscope/flow cytometry & Detailed information & $\begin{array}{l}\text { Error prone, dyes needed, expen- } \\
\text { sive }\end{array}$ & {$[20,21]$} \\
\hline & $\begin{array}{l}\text { Plate out (Colony forming Units } \\
\text { (CfUs)) }\end{array}$ & Standard lab equipment sufficient & $\begin{array}{l}\text { Error prone, time consuming, } \\
\text { laborious }\end{array}$ & {$[18,20,22,23]$} \\
\hline Product specific assays & $\begin{array}{l}\text { SDS-Page, Western blot, ELISA, } \\
\text { enzyme assays }\end{array}$ & Product specific & $\begin{array}{l}\text { Time consuming, laborious, } \\
\text { manual intervention }\end{array}$ & {$[12,13,15,24]$} \\
\hline Particle size distribution & $\begin{array}{l}\text { Light scattering (e.g. Coulter Multi- } \\
\text { sizer II, Nanophox PCCS) }\end{array}$ & Detailed information & $\begin{array}{l}\text { Manual intervention, time con- } \\
\text { suming }\end{array}$ & {$[13,18,19,24]$} \\
\hline
\end{tabular}

Only by such a tool unnecessary cell disruption cycles in manufacturing can be avoided and therefore product loss minimized.

In the present study, we demonstrate how an HPLC method in combination with automated data analysis, which we originally developed for monitoring $E$. coli cell integrity during bioreactor cultivations [25], can solve the current issues in evaluating cell disruption efficiency. We compared different methods to evaluate cell disruption efficiency by high-pressure homogenization (Table 1) and proved the applicability of our automated method, which will definitely facilitate and accelerate bioprocess development in the future, since it describes a powerful tool applicable across unit operations. We did not investigate the effects of cell disruption strategies on product loss, since this is highly product-specific and thus must be evaluated on a case-by-case basis, but rather provide a platform tool to automatically evaluate cell disruption efficiency at-line.

\section{Materials and methods}

\section{Chemicals}

All chemicals were purchased from Carl Roth $\mathrm{GmbH}$ (Vienna, Austria), if not stated otherwise.

\section{Strains and cultivations Strain}

All experiments were performed with a recombinant E.coli BL21(DE3) strain producing a recombinant single chain fragment variable ( $\mathrm{scFv}$ ) against gliadin, which causes coeliac disease [26].

\section{Shake flask cultivations}

A $500 \mathrm{~mL}$ shake flask (SF) containing $50 \mathrm{~mL}$ sterile Super Broth medium (tryptone $32 \mathrm{~g} / \mathrm{L}$, yeast extract $20 \mathrm{~g} / \mathrm{L}$, $\mathrm{NaCl} 5 \mathrm{~g} / \mathrm{L}, \mathrm{pH} 7.2 \pm 0.2)$ supplemented with $50 \mu \mathrm{g} /$ $\mathrm{mL}$ kanamycin (SB-Kan) was inoculated from a frozen stock $\left(1.5 \mathrm{~mL},-80{ }^{\circ} \mathrm{C}\right)$. This pre-culture was incubated at $37^{\circ} \mathrm{C}$ and $230 \mathrm{rpm}$ in an Infors HR Multitron shaker
(Infors, Bottmingen, Switzerland) for $12 \mathrm{~h}$. Then, $490 \mathrm{~mL}$ sterile SB-Kan in a $2500 \mathrm{~mL}$ ultra-high-yield SF were inoculated with $10 \mathrm{~mL}$ pre-culture. The main culture was incubated at $37{ }^{\circ} \mathrm{C}$ and $230 \mathrm{rpm}$ until the optical density at $600 \mathrm{~nm}\left(\mathrm{OD}_{600}\right)$ reached between 0.5 and 0.7. Then the culture was induced with $1 \mathrm{mM}$ isopropyl $\beta$-D-1thiogalactopyranoside (IPTG) for $16 \mathrm{~h}$. To estimate the dry cell weight (DCW) of the cultivation broth an already generated $\mathrm{OD}_{600}-\mathrm{DCW} / \mathrm{L}$ correlation was used (Eq. 1),

$$
y=0.451 \cdot x,
$$

where $x$ represents the measured $\mathrm{OD}_{600}$ value and $y$ the DCW/L cultivation broth. Thus, aliquots with predefined biomass (BM) concentrations for subsequent homogenization were prepared.

\section{Bioreactor cultivations}

Bioreactor cultivations were performed according to our previous study [27]. In short, $500 \mathrm{~mL}$ pre-culture (DeLisa medium [28]; $50 \mu \mathrm{g} / \mathrm{mL}$ kanamycin) were used to inoculate $4500 \mathrm{~mL}$ sterile DeLisa medium in a stainless steel Sartorius Biostat Cplus bioreactor (Sartorius, Göttingen, Germany) with a working volume of $10 \mathrm{~L}$. After a batch and a non-induced fed-batch, cells were induced by $1 \mathrm{mM}$ IPTG at $30^{\circ} \mathrm{C}$ for $8 \mathrm{~h}$.

\section{Harvest and cell disruption}

The cultivation broth was aliquoted and cells were harvested by centrifugation ( $\left.4500 \mathrm{rpm}, 4{ }^{\circ} \mathrm{C}, 30 \mathrm{~min}\right)$. Supernatants were discarded and cell aliquots were either frozen at $-20{ }^{\circ} \mathrm{C}$, representing a potential holding step in the process (Fig. 1), or processed immediately. Prior to cell disruption, frozen or fresh biomass (BM) pellets were resuspended in $50 \mathrm{mM}$ TRIS-HCl buffer, $\mathrm{pH}$ 8.0. Cell suspensions were adjusted to $10 \mathrm{~g} \mathrm{DCW} / \mathrm{L}$, if not stated otherwise.

In the present study, we performed cell disruption by high-pressure homogenization using a PandaPLUS 2000 (GEA Mechanical Equipment, Parma; Italia). At first, 
resuspended BM was pumped in cycles through the homogenizer to remove residual air. After applying the pre-pressure, the main-pressure was adjusted to $1500 \mathrm{bar}$ to disrupt the cells, if not stated otherwise. To limit heat generation, BM was kept on ice and a cooling unit was connected to the outlet of the homogenizer. After resuspending biomass in TRIS-HCl buffer (hereafter referred to as "0 sample"), as well as after each homogenization cycle (up to five cycles), samples were taken. Samples were centrifuged $\left(14,000 \mathrm{rpm}, 4{ }^{\circ} \mathrm{C}, 15 \mathrm{~min}\right)$, and the supernatants were used for further analyses.

\section{Analytical methods}

\section{HPLC-measurements}

Data acquisition UV chromatographic data were acquired using the PATfinder ${ }^{\mathrm{TM}}$ analytical device (BIAseparations, Ajdovščina, Slovenia) comprising of an autosampler (Optimas), a pump (Azura P 6.1L), a UV detector (Azura MWD 2.1L) and a monolithic CIMac QA column $(0.1 \mathrm{~mL})$. UV chromatographic data at $280 \mathrm{~nm}$ were recorded at $5 \mathrm{~Hz}$ to monitor the total protein content. According to our previous study, where we successfully used this setup for monitoring cell integrity during bioreactor cultivations [25], the monolithic column was equilibrated with 10 column volumes $(\mathrm{CV})$ of loading buffer (50 mM TRIS- $\mathrm{HCl}$ buffer, pH 8.0), followed by $50 \mu \mathrm{L}$ of sample injection and a post injection wash of $10 \mathrm{CV}$ loading buffer. The bound proteins and nucleic acids were eluted with $100 \%$ elution buffer $(50 \mathrm{mM}$ Tris- $\mathrm{HCl}, 1 \mathrm{M}$ $\mathrm{NaCl}, \mathrm{pH}$ 8) for $10 \mathrm{CV}$ before the column was stripped with $1 \mathrm{M} \mathrm{NaOH} / 2 \mathrm{M} \mathrm{NaCl}$ for $10 \mathrm{CV}$ to avoid carry over. The flow velocity was maintained at $280 \mathrm{~cm} / \mathrm{h}$ throughout the whole HPLC run resulting in a total analysis time of 5 min per sample.

Automated data processing The total areas under the curve (AUC) for the flowthrough (FT) and elution (EL) peaks were used to follow the relative increase of the protein content in the supernatants after homogenization. The individual chromatograms from samples at different steps were automatically imported using MATLAB (Mathworks, US; vR2016a). A reference spectrum was generated based on the arithmetic mean or average of all imported UV chromatograms at $280 \mathrm{~nm}$, since this is a prerequisite for peak alignment and generation of chromatogram fingerprints. Peak alignment was done in MATLAB using icoshift [29]. Thereon, automated integration of the peaks in the region of interest, namely FT and EL, was done using the Trapz function in MATLAB. Finally, the AUC was used to calculate the relative recovery of proteins. The relative increase of total protein content was calculated using Eq. 2,
Relative protein recovery $=\frac{A U C_{i}-A U C_{\text {Start }}}{A U C_{\text {End }}-A U C_{\text {Start }}} * 100$,

where $\mathrm{AUC}_{\mathrm{i}}$ is the total $\mathrm{AUC}$ of sample $\mathrm{I}, \mathrm{AUC}_{\text {Start }}$ the total AUC of the first sample and $\mathrm{AUC}_{\mathrm{End}}$ is the total AUC of the last sample.

\section{Reference analytics}

We used several established state-of-the-art reference analytics to evaluate cell disruption efficiency, and thus our methodology based on HPLC and automated data analysis.

Protein concentration We determined the total protein content by the Bradford Coomassie Blue assay (SigmaAldrich, Vienna, Austria) and used bovine serum albumin as standard. To stay in the linear range of the UV detector (Genesys 20, Thermo Scientific, Waltham, MA, USA) from 0.1 to 0.8 absorption units, samples were diluted with water, when necessary.

Colony forming Units (CfUs) To judge viable cell reduction, we determined the Colony forming Units (CfUs). For that purpose, cell suspensions were diluted with sterile $0.9 \%(\mathrm{w} / \mathrm{v}) \mathrm{NaCl}$ solution in 1:10 steps ranging from $10^{0}$ to $10^{-16} .100 \mu \mathrm{L}$ of each dilution were plated out on selective Agar plates $(10 \mathrm{~g} / \mathrm{L}$ tryptone, $5 \mathrm{~g} / \mathrm{L}$ yeast extract, $10 \mathrm{~g} / \mathrm{L}$ $\mathrm{NaCl}, 15 \mathrm{~g} / \mathrm{L}$ plate count agar, $\mathrm{pH}$ 7.5) containing $50 \mu \mathrm{g} /$ $\mathrm{mL}$ kanamycin. After incubation at $35^{\circ} \mathrm{C}$ for $48 \mathrm{~h}$, formed colonies were counted.

Flow cytometric ( $F C$ ) measurements Flow cytometric (FC) analysis was carried out according to Langemann et al. [30]. Samples were diluted with particle-free, sterile $0.9 \%(\mathrm{w} / \mathrm{v}) \mathrm{NaCl}$ solution, to avoid oversaturation of the detector $\left(\right.$ CyFlow $^{\circledR}$ Cube 8 flow cytometer; Partec, Münster, Germany). RH414 (abs./em. 532/760 nm, directed to plasma membranes) and DiBAC4(3) (abs./ em. 493/516 nm, membrane potential-sensitive dye) dyes were mixed with the samples shortly before analysis. Using both dyes concomitantly, quantification of all cells (RH414), dead cells [DiBAC4(3)] and viable cells [signal of RH414 minus signal of DiBAC4(3)] was possible. Measurements were recorded by the CyView Cube 15 software and evaluated with FCS Express V4 (DeNovo Software; Los Angeles, CA, USA).

Dielectric spectroscopy (DS) Dielectric spectroscopy (DS) is usually used to follow viable cell concentrations (VCC) in upstream processes [31]. In this study, DS was used to track viable cell reduction, as an additional method. Low radio frequencies lead to a polarization of 
cells due to charge separation effects. At high frequencies, no polarization of cells can be observed. Here mainly background, such as water dipoles, is measured [32]. In this study, two frequencies, $1 \mathrm{MHz}$ for viable bacterial cells and $10 \mathrm{MHz}$ for non-cellular background, were used during dielectric measurements in standard dual-frequency measuring mode [33]. The difference between those two frequencies led to the measured parameter, namely delta capacitance. Measurements were performed with a FOGALE nanotech probe (HAMILTON Bonaduz AG, Bonaduz, Switzerland). Its signal was logged using the Evobox software (HAMILTON Bonaduz AG, Bonaduz, Switzerland). Untreated and disrupted cell suspensions were measured for at least $3 \mathrm{~min}$. The mean value of this signal was used for the calculation of percental signal reduction corresponding to the decrease in cell viability.

\section{Experimental design}

The experiments in this study were divided into three work packages (WPs), namely WP1. State-of-the-art methods compared to HPLC combined with automated data analysis, WP2. Effect of freezing on cell disruption efficiency, and WP3. Development of a cell disruption process by a design of experiment approach. More details about the three WPs are given in Table 3.

\section{WP1. State-of-the-art methods compared to HPLC combined with automated data analysis}

The goal of this WP was to evaluate the applicability and accuracy of our method of HPLC and automated data analysis, which we successfully used in upstream processing [25], to analyze cell disruption efficiency. Thus, we wanted to demonstrate the applicability of our tool across unit operations. In WP1, we homogenized resuspended E. coli $\mathrm{BM}$ at 1500 bar for five cycles and analyzed the disruption efficiency by five different methods (Table 3).

\section{WP2. Effect of freezing on cell disruption efficiency}

Different factors, like time management and occupancy of equipment, can cause the necessity of holding steps in a production process. Freezing the BM after harvesting presents such a typical holding step (Fig. 1). In WP2, we analyzed potential effects of freezing on cell disruption efficiency. Thus, resuspended BM was either homogenized directly or frozen at $-20{ }^{\circ} \mathrm{C}$ for at least $24 \mathrm{~h}$, followed by thawing at $4{ }^{\circ} \mathrm{C}$ and high-pressure homogenization at 1500 bar for five cycles (Table 3).

\section{WP3. Development of a cell disruption process by a design of experiment approach}

The goal of WP3 was to evaluate the effect of the three factors "biomass concentration (10-100 g DCW/L)", "number of cycles (0-3)" and "homogenization pressure (500-1500 bar)" on cell disruption efficiency. For that purpose, we designed a full factorial screening study using the software MODDE10 (Umetrics, Umeå, Sweden). The respective design space is shown in Fig. 2.

\section{Results and discussion \\ WP1. State-of-the-art methods compared to HPLC combined with automated data analysis}

In WP1, we compared different methods to evaluate cell disruption efficiency. In Fig. 3 the respective raw data are shown.

To be able to easily compare the different analytical methods, the respective raw data were normalized and are shown relatively in \% in Table 4.

As shown in Table 4, all five analytical methods gave comparable results. After the first homogenization cycle at 1500 bar, around $80-90 \%$ of the cells were disrupted. The second homogenization cycle reduced the amount of intact cells by another $5-10 \%$, whereas following homogenization cycles only resulted in minor additional cell disruption. By this comparative analysis, we were able to prove that our method of using HPLC followed by

Table 3 Overview of the three experimental work packages (WPs)

\begin{tabular}{|c|c|c|c|}
\hline WP & Strategy & Analytics & Goal \\
\hline 1 & $\begin{array}{l}\text { DCW: } 10 \mathrm{~g} / \mathrm{L} \\
\text { Pressure: } 1500 \text { bar } \\
\text { Cycles: } 0-5\end{array}$ & $\begin{array}{l}\text { Bradford = state-of-the-art } \\
\text { Flow cytometry = state-of-the-art } \\
\text { CfUs = state-of-the-art } \\
\text { Dielectric spectroscopy = additional method } \\
\text { HPLC and automated data analysis = novel method }\end{array}$ & Evaluation of applicability and accuracy of our method \\
\hline 2 & $\begin{array}{l}\text { DCW: } 10 \mathrm{~g} / \mathrm{L} \\
\text { Pressure: } 1500 \text { bar } \\
\text { Cycles: } 0-5\end{array}$ & $\begin{array}{l}\text { Bradford } \\
\text { HPLC and automated data analysis }\end{array}$ & Analyzing potential effects of freezing on cell disruption efficiency \\
\hline 3 & $\begin{array}{l}\text { DCW: } 10-100 \mathrm{~g} / \mathrm{L} \\
\text { Pressure: } 500-1500 \text { bar } \\
\text { Cycles: } 0-3\end{array}$ & $\begin{array}{l}\text { Bradford } \\
\text { HPLC and automated data analysis }\end{array}$ & $\begin{array}{l}\text { Evaluation the effect of BM concentration, pressure and cycles on } \\
\text { cell disruption }\end{array}$ \\
\hline
\end{tabular}




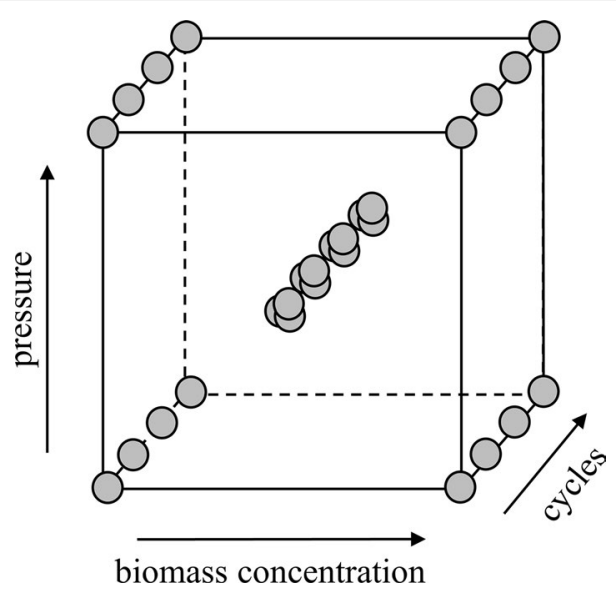

Fig. 2 Design space and respective experiments of the full factorial screening study performed in WP3. Homogenization pressure (500, 1000 and 1500 bar) and cell density (10,55 and $100 \mathrm{~g} \mathrm{DCW/L)} \mathrm{were}$ used as quantitative factors. The number of homogenization cycles $(0,1,2$ and 3$)$ was used as a quantitative multilevel factor

automated data analysis describes a valid tool, not only to follow cell integrity in the USP, but also to monitor cell disruption efficiency in the DSP. Compared to the stateof-the-art methods, our method is automated, only takes 5 min per sample and can be implemented at-line.

\section{WP2. Effect of sample freezing on cell disruption efficiency}

Freezing of BM after harvest describes a common hold step in a recombinant protein production process (indicated in red in Fig. 1). In WP2, we investigated whether freezing affects the subsequent cell disruption efficiency. For that purpose, we homogenized BM, either directly after harvest or thawed at $4{ }^{\circ} \mathrm{C}$ after previous freezing at $-20{ }^{\circ} \mathrm{C}$, for three cycles at 1500 bar. In this WP, we only investigated three homogenization cycles, since in WP1 we had found that additional cycles did not significantly contribute to cell disruption (Table 4). We analyzed the respective supernatants by Bradford measurements and HPLC followed by automated data analysis. As shown in Fig. 4, both analytical methods reveal the same outcome. The first homogenization cycle reduced the amount of intact cells by a factor of around $90 \%$, no matter if the BM had been frozen before or not. The following homogenization cycles only slightly increased the amount of disrupted cells in both cases. However, when BM had been frozen before, around twice the amount of protein was measured already before homogenization indicating that cells had already lysed by freezing/thawing (Fig. 4). Nonetheless, we concluded that freezing the BM after harvest is an acceptable hold step in a recombinant protein production process, as it does not affect the cell disruption efficiency by high-pressure homogenization. However, potential effects of freezing on the recombinant product have to be evaluated on a case-by-case basis as those effects are product-specific.

\section{WP3. Development of a cell disruption process by a design} of experiment approach

According to literature, no difference in homogenization efficiency is seen if BM concentrations are kept below $12.5 \mathrm{~g} \mathrm{DCW} / \mathrm{L}$ [18]. Also, protein release was found to be insufficient at a pressure below 500 bar [18]. Hence, for the DoE screening design we investigated BM concentrations from 10 to $100 \mathrm{~g} \mathrm{DCW/L}$, as well as pressure settings from 500 to 1500 bar. Furthermore, we investigate the number of homogenization cycles between 0 and 3 . The respective design space is shown in Fig. 2. We used Bradford measurements as well as HPLC followed by automated data analysis to monitor cell disruption efficiency under the different conditions. Both analytical methods showed no significant difference, underlining the validity of the novel method we present here. In Fig. 5 a contour plot showing the results of the DoE screening design evaluated by HPLC and automated data analysis is shown. To be able to directly compare the effect of the different factors on cell disruption efficiency, the AUC signals were normalized to the biomass before multivariate data evaluation.

As shown in Fig. 5, cell disruption efficiency increased with an increasing number of homogenization cycles at 1500 bar and low biomass concentrations. With respect to biomass concentration and homogenization efficiency, literature is quite inconsistent, as some studies report no effect [22], while others do [34, 35]. In our study, we observed higher disruption efficiency for samples with lower biomass concentration. The homogenization pressure had no significant impact on cell disruption efficiency in the tested ranges ( $p$ value $=0.87$ ). We did not investigate the effect of these settings on the recombinant product, since the impact of pressure and number of homogenization cycles is certainly product-dependent. However, we provide an automated platform methodology to evaluate cell disruption efficiency, which will enable fast development of a cell disruption strategy tailored to specific products allowing both high cell disruption efficiency and prevention of product loss. 
$\mathbf{a}$

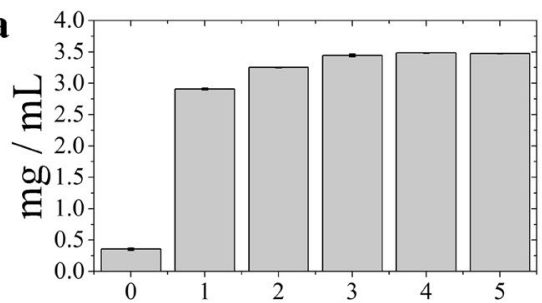

number of cycles

c

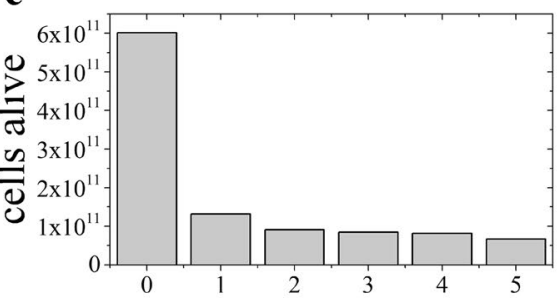

number of cycles

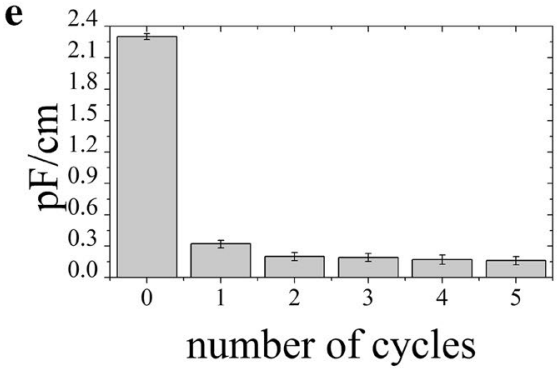

b

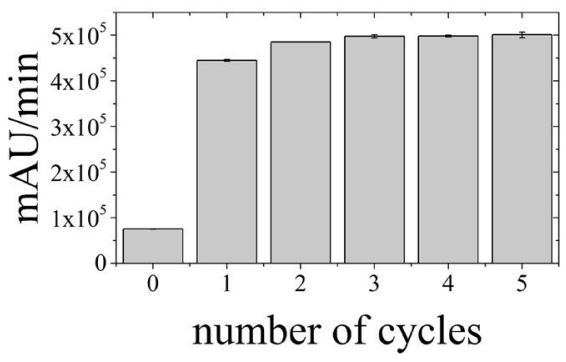

d

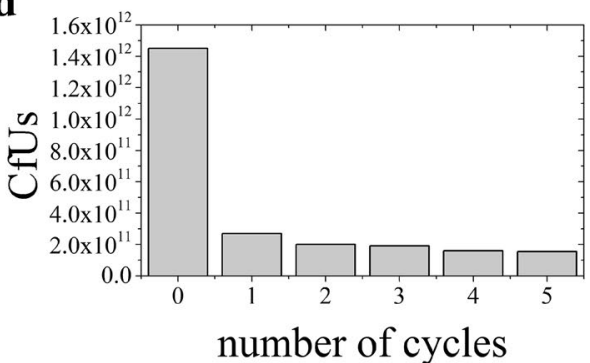

$\underline{\mathbf{f}}$

\begin{tabular}{c|c|c|c|c|c|c|c|c}
\hline \multirow{2}{*}{ cycle } & \multicolumn{2}{|c|}{ HPLC } & \multicolumn{2}{c|}{ protein content } & \multicolumn{2}{c|}{$\begin{array}{c}\text { dielectric } \\
\text { spectroscopy }\end{array}$} & CfUs & $\begin{array}{c}\text { flow } \\
\text { cytometry }\end{array}$ \\
\hline & $\mathrm{MV}$ & $\mathrm{SD}$ & $\mathrm{MV}$ & $\mathrm{SD}$ & $\mathrm{MV}$ & $\mathrm{SD}$ & & \\
\hline & $\mathrm{mAU} / \mathrm{min}$ & $\%$ & $\mathrm{mg} / \mathrm{mL}$ & $\%$ & $\mathrm{pF} / \mathrm{cm}$ & $\%$ & $\mathrm{CfU}$ & cells alive \\
\hline 0 & 75146.37 & 1.05 & 0.35 & 4.21 & 2.30 & 1.26 & $14.5^{*} 10^{11}$ & $60.1^{*} 10^{10}$ \\
\hline 1 & 444859.91 & 0.53 & 2.91 & 6.05 & 0.32 & 14.09 & $2.7^{*} 10^{11}$ & $13.2^{*} 10^{10}$ \\
\hline 2 & 485065.79 & 0.06 & 3.25 & 12.23 & 0.20 & 8.56 & $2.0^{*} 10^{11}$ & $9.1 * 10^{10}$ \\
\hline 3 & 497337.71 & 0.70 & 3.44 & 9.54 & 0.19 & 8.09 & $1.9^{*} 10^{11}$ & $8.5^{*} 10^{10}$ \\
\hline 4 & 498225.25 & 0.36 & 3.48 & 1.78 & 0.17 & 25.89 & $1.6^{*} 10^{11}$ & $8.2^{*} 10^{10}$ \\
\hline 5 & 500833.19 & 1.27 & 3.47 & 0.36 & 0.16 & 9.21 & $1.6^{*} 10^{11}$ & $6.7^{*} 10^{10}$ \\
\hline
\end{tabular}

Fig. 3 Raw data obtained from different analytical methods to evaluate cell disruption efficiency. a Total released protein ( $\mathrm{mg} / \mathrm{mL}$ ) determined by Bradford, $\mathbf{b}$ area under the curve (AUC) measured with HPLC, c decrease of viable cells determined by flow cytometric measurements, $\mathbf{d}$ decrease of Colony forming Units (CfUs) and e reduction of the dielectric spectroscopy signal. f Summary of data: actual values, as mean value (MV) with standard deviation (SD), if analytics was performed in triplicates 
Table 4 Comparison of normalized data from five different analytical methods to evaluate cell disruption efficiency

\begin{tabular}{lcrrrrr}
\hline Cycle & \multicolumn{2}{l}{$\begin{array}{l}\text { Total protein con- } \\
\text { tent [\%] }\end{array}$} & & Signal reduction [\%] & \multicolumn{2}{l}{$\begin{array}{l}\text { Viable cells } \\
\text { [\%] }\end{array}$} \\
\cline { 2 - 3 } & Bradford & HPLC & DS & CfUs & FC \\
\hline 0 & 10.2 & 15.0 & 100.0 & 100.0 & 100.0 \\
1 & 83.8 & 88.8 & 13.9 & 18.3 & 21.9 \\
2 & 93.7 & 96.9 & 8.7 & 13.8 & 15.1 \\
3 & 99.2 & 99.3 & 8.3 & 13.1 & 14.1 \\
4 & 100.3 & 99.5 & 7.4 & 11.0 & 13.6 \\
5 & 100.0 & 100.0 & 7.1 & 10.7 & 11.1 \\
\hline
\end{tabular}

The total protein content after five cycles was considered to be $100 \%$. Based on this assumption \%-values for the other cycles were calculated

\section{Conclusions}

Cell disruption is a key unit operation to access recombinant intracellular protein from $E$. coli. Thus, monitoring tools are needed to evaluate cell disruption strategies and resulting cell disruption efficiency. However, current state-of-the-art methods are time-delayed, slowing down process development, and require manual intervention, making them error-prone. In the present study, we applied a methodology comprising HPLC and automated data analysis, which we recently developed to monitor upstream processes, to evaluate cell disruption efficiency of high-pressure homogenization. Our findings can be summarized as:

- HPLC followed by automated data analysis outcompetes current state-of-the-art methods to monitor cell disruption efficiency, as it is faster and does not require manual intervention.

- Freezing of BM prior to high-pressure homogenization has no impact on cell disruption efficiency.

- The biomass concentration and the number of homogenization cycles affect cell disruption efficiency, whereas the pressure can be varied between 500 and 1500 bar without significant impact.

We are convinced that our methodology will be the golden standard to evaluate cell disruption processes in the future as it can be implemented at-line, gives results within minutes after sampling and does not need manual intervention. This tool does not only allow the fast development of cell disruption strategies specifically tailored to protect the product, but actually describes a useful tool applicable across unit operations.
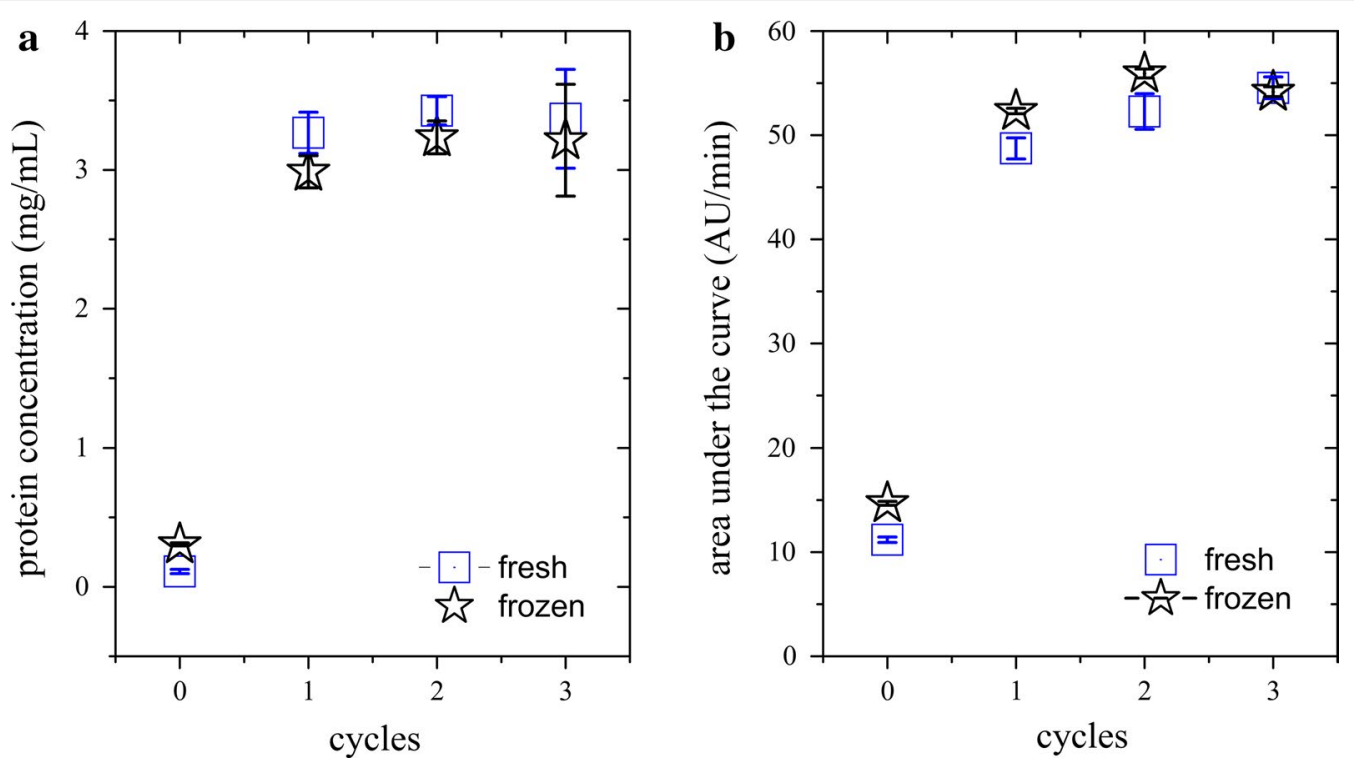

Fig. 4 Disruption efficiency monitored by (a), Bradford measurements or (b), HPLC followed by automated data analysis. Stars, frozen biomass; squares, fresh biomass 


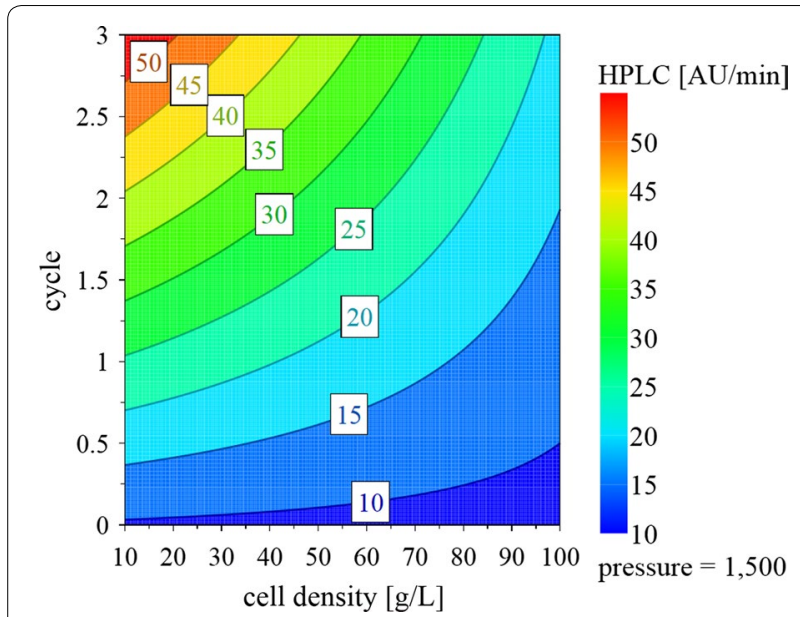

Fig. 5 Response contour plot of protein release during high-pressure homogenization. Goodness of fit $\left(R^{2}\right)=0.892$; goodness of prediction $\left(Q^{2}\right)=0.813$

\section{Abbreviations}

AU: absorption units; AUC: area under the curve; BM: biomass; CfUs: Colony forming Units; CV: column volume; DCW: dry cell weight; DoE: design of experiment; DS: dielectric spectroscopy; DSP: downstream processing; EL: elution; FC: flow cytometry; FT: flow through; IB: inclusion body; IPTG: isopropyl $\beta$-D-1-thiogalactopyranoside; $\mathrm{MV}$ : mean value; $\mathrm{OD}_{600}$ : optical density measured at $600 \mathrm{~nm}$; SB: super broth; SB-Kan: super broth supplemented with $50 \mu \mathrm{g} / \mathrm{mL}$ kanamycin; scFv: single chain fragment variable; SD: standard deviation; SF: shake flask; USP: upstream processing; WPs: work packages.

\section{Authors' contributions}

$\mathrm{BE}$ and OS performed and evaluated the experiments. DJW performed all fermentations and provided biomass. VR executed and evaluated HPLC measurements. JF assisted with dielectric spectroscopy measurements. OS planned and supervised the study. BE and OS designed the study. CH initiated the study and gave valuable scientific input. BE and OS wrote the manuscript. All authors read and approved the final manuscript.

\section{Author details}

${ }_{1}^{1}$ Research Division Biochemical Engineering, Institute of Chemical, Environmental and Biological Engineering, TU Wien, Gumpendorfer Strasse 1a, 1060 Vienna, Austria. ${ }^{2}$ Christian Doppler Laboratory for Mechanistic and Physiological Methods for Improved Bioprocesses, Institute of Chemical, Environmental and Biological Engineering, TU Wien, Gumpendorferstraße 1a, 1060 Vienna, Austria.

\section{Acknowledgements}

The authors acknowledge the TU Wien University Library for financial support through its Open Access Funding Programme. The authors acknowledge Sciotec Diagnostic Technologies for providing the used strain.

\section{Competing interests}

The authors declare that they have no competing interests.

\section{Availability of data materials}

The datasets used and/or analyzed during the current study are available from the corresponding author on reasonable request.

\section{Consent for publication}

Not applicable.

\section{Ethics approval and consent to participate}

Not applicable.
Funding

Not applicable.

\section{Publisher's Note}

Springer Nature remains neutral with regard to jurisdictional claims in published maps and institutional affiliations.

Received: 27 April 2017 Accepted: 24 July 2017

Published online: 01 August 2017

\section{References}

1. Baeshen MN, Al-Hejin AM, Bora RS, Ahmed MM, Ramadan HA, Saini KS, Baeshen NA, Redwan EM. Production of biopharmaceuticals in $E$. coli: current scenario and future perspectives. J Microbiol Biotechnol. 2015;25:953-62.

2. Spadiut O, Capone S, Krainer F, Glieder A, Herwig C. Microbials for the production of monoclonal antibodies and antibody fragments. Trends Biotechnol. 2014;32:54-60.

3. Tripathi NK. Production and purification of recombinant proteins from Escherichia coli. ChemBioEng Rev. 2016;3:116-33.

4. Graslund S, Nordlund P, Weigelt J, Hallberg BM, Bray J, Gileadi O, Knapp $\mathrm{S}$, Oppermann U, Arrowsmith C, Hui R, et al. Protein production and purification. Nat Methods. 2008;5:135-46.

5. Kotzsch A, Vernet E, Hammarström M, Berthelsen J, Weigelt J, Gräslund S, Sundström M. A secretory system for bacterial production of high-profile protein targets. Protein Sci. 2011;20:597-609.

6. Mergulhão FJM, Summers DK, Monteiro GA. Recombinant protein secretion in Escherichia coli. Biotechnol Adv. 2005;23:177-202.

7. Gupta SK, Shukla P. Microbial platform technology for recombinant antibody fragment production: a review. Crit Rev Microbiol. 2017:43:31-42.

8. Hettwer D, Wang H. Protein release from Escherichia coli cells permeabilized with guanidine-HCl and Triton X100. Biotechnol Bioeng. 1989;33:886-95.

9. Feliciello I, Chinali G. A modified alkaline lysis method for the preparation of highly purified plasmid DNA from Escherichia coli. Anal Biochem. 1993;212:394-401.

10. Balasundaram B, Harrison S, Bracewell DG. Advances in product release strategies and impact on bioprocess design. Trends Biotechnol. 2009;27:477-85.

11. Middelberg APJ. Process-scale disruption of microorganisms. Biotechnol Adv. 1995;13:491-551.

12. Peternel Š, Komel R. Isolation of biologically active nanomaterial (inclusion bodies) from bacterial cells. Microb Cell Fact. 2010;9:66.

13. Van Hee P, Middelberg AP, Van Der Lans RG, Van Der Wielen LA. Relation between cell disruption conditions, cell debris particle size, and inclusion body release. Biotechnol Bioeng. 2004;88:100-10.

14. Benov L, Al-Ibraheem J. Disrupting Escherichia coli: a comparison of methods. J Biochem Mol Biol. 2002;35:428-31.

15. Singh R. A comparative study on cell disruption methods for release of aspartase from E. coli K-12. Indian J Exp Biol. 2013;51:997-1003.

16. Balasundaram B, Harrison ST. Study of physical and biological factors involved in the disruption of E. coli by hydrodynamic cavitation. Biotechnol Prog. 2006;22:907-13.

17. Balasundaram B, Pandit AB. Selective release of invertase by hydrodynamic cavitation. Biochem Eng J. 2001;8:251-6.

18. Ramakrishnan NR, Tey BT, Tau CL, Ariff A. Classification of pressure range based on the characterization of Escherichia coli cell disruption in high pressure homogenizer. Am J Biochem Biotechnol. 2009;5:21-9.

19. Li Q, Aucamp JP, Tang A, Chatel A, Hoare M. Use of focused acoustics for cell disruption to provide ultra scale-down insights of microbial homogenization and its bioprocess impact-recovery of antibody fragments from rec E. coli. Biotechnol Bioeng. 2012;109:2059-69.

20. Diels AM, De Taeye J, Michiels CW. Sensitisation of Escherichia coli to antibacterial peptides and enzymes by high-pressure homogenisation. Int J Food Microbiol. 2005;105:165-75.

21. Middelberg APJ. 2 microbial cell disruption by high-pressure homogenization. In: Desai MA, editor. Downstream processing of proteins: methods and protocols. Totowa: Humana Press; 2000. p. 11-21. 
22. Diels AM, Callewaert L, Wuytack EY, Masschalck B, Michiels CW. Inactivation of Escherichia coli by high-pressure homogenisation is influenced by fluid viscosity but not by water activity and product composition. Int J Food Microbiol. 2005;101:281-91.

23. Wuytack EY, Diels AM, Michiels CW. Bacterial inactivation by high-pressure homogenisation and high hydrostatic pressure. Int J Food Microbiol. 2002;77:205-12.

24. Agerkvist I, Enfors S-O. Characterization of E. coli cell disintegrates from a bead mill and high pressure homogenizers. Biotechnol Bioeng. 1990;36:1083-9.

25. Rajamanickam V, Wurm D, Slouka C, Herwig C, Spadiut O. A novel toolbox for E. coli lysis monitoring. Anal Bioanal Chem. 2017;409:667-71.

26. Stadlmann V, Harant H, Korschineck I, Hermann M, Forster F, Missbichler A Novel avian single-chain fragment variable (scFv) targets dietary gluten and related natural grain prolamins, toxic entities of celiac disease. BMC Biotechnol. 2015;15:109.

27. Wurm DJ, Veiter L, Ulonska S, Eggenreich B, Herwig C, Spadiut O. The E. coli pET expression system revisited-mechanistic correlation between glucose and lactose uptake. Appl Microbiol Biotechnol. 2016;100:8721-9.

28. DeLisa MP, Li J, Rao G, Weigand WA, Bentley WE. Monitoring GFPoperon fusion protein expression during high cell density cultivation of Escherichia coli using an on-line optical sensor. Biotechnol Bioeng. 1999;65:54-64.

29. Tomasi G, Savorani F, Engelsen SB. Icoshift: an effective tool for the alignment of chromatographic data. J Chromatogr A. 2011;28:7832-40.
30. Langemann T, Mayr UB, Meitz A, Lubitz W, Herwig C. Multi-parameter flow cytometry as a process analytical technology (PAT) approach for the assessment of bacterial ghost production. Appl Microbiol Biotechnol. 2016;100:409-18.

31. Slouka C, Wurm DJ, Brunauer G, Welzl-Wachter A, Spadiut O, Fleig J, Herwig C. A novel application for low frequency electrochemical impedance spectroscopy as an online process monitoring tool for viable cell concentrations. Sensors. 2016;16:1900.

32. Davey HM, Davey CL, Woodward AM, Edmonds AN, Lee AW, Kell DB. Oscillatory, stochastic and chaotic growth rate fluctuations in permittistatically controlled yeast cultures. BioSystems. 1996;39:43-61.

33. Ehgartner D, Sagmeister P, Herwig C, Wechselberger P. A novel real-time method to estimate volumetric mass biodensity based on the combination of dielectric spectroscopy and soft-sensors. J Chem Technol Biotechnol. 2015;90:262-72.

34. Kleinig AR, Mansell CJ, Nguyen QD, Badalyan A, Middelberg APJ. Influence of broth dilution on the disruption of Escherichia coli. Biotechnol Tech. 1995;9:759-62.

35. Garcia-Ortega X, Reyes C, Montesinos JL, Valero F. Overall key performance indicator to optimizing operation of high-pressure homogenizers for a reliable quantification of intracellular components in Pichia pastoris. Front Bioeng Biotechnol. 2015;3:107.

\section{Submit your next manuscript to BioMed Central and we will help you at every step:}

- We accept pre-submission inquiries

- Our selector tool helps you to find the most relevant journal

- We provide round the clock customer support

- Convenient online submission

- Thorough peer review

- Inclusion in PubMed and all major indexing services

- Maximum visibility for your research

Submit your manuscript at www.biomedcentral.com/submit 